\title{
Abundance of bacteria and fungi in seagrass and mangrove detritus
}

\author{
L. K. Blum, A. L. Mills, J. C. Zieman, R. T. Zieman \\ Department of Environmental Sciences, University of Virginia, Charlottesville, Virginia 22903, USA
}

\begin{abstract}
Microbial (bacterial and fungal) biomass associated with decaying Thalassia testudinum, Syringodium filiforme, Halodule wrightii, and Rhizophora mangle, incubated in litter bags in Florida Bay, was estimated from direct microscopic determinations of microbial abundance and cell volume. Bacterial biomass predominated throughout decomposition, with fungi usually constituting 0 to $20 \%$ of the total microbial biomass. Total microbial biomass was never greater than $1.2 \%$ of detrital mass, and in most cases was substantially less than $1.0 \%$. Based on these results, it is unlikely that detritivores that feed by ingestion of detrital particles can rely solely on microorganisms as an energy source.
\end{abstract}

\section{INTRODUCTION}

Microorganisms are important components of the detritus complex for several reasons. Microbes are responsible for mineralization of plant nutrients, and their activities increase the nutritive value of detritus by mineralizing plant carbon and assimilating nitrogen, thus decreasing the $\mathrm{C} / \mathrm{N}$ ratio. While some authors assert that bacteria are the principal carbon and energy source for detritivores (Newell 1965, Fenchel \& Jørgensen 1977, Lopez et al. 1977), others have found that bacteria do not comprise a significant portion of the detrital mass (Iverson 1973, Cammen 1980, Rublee 1982, Newell \& Field 1983, Findlay \& Meyer 1984) so that detritivores would have difficulty in obtaining required carbon and nitrogen solely from bacterial biomass. The studies cited above considered only the contribution of bacterial biomass to the detrital complex, and not that of the total microbiota, i.e. bacteria and fungi.

Fungal hyphae, like bacterial cells, have a low $\mathrm{C} / \mathrm{N}$ ratio (Newell \& Statzell-Tallman 1982), and in combination with bacteria may constitute a substantial portion of the detrital mass. Although the bacterial biomass associated with detrital particles is not likely to be sufficient to meet detritivores' carbon and energy requirements, if fungi comprise a substantial portion of the detrital particle, then the combined bacterial and fungal biomass of detritus might be sufficient to provide detritivores with all of their carbon and energy requirements. In studies of standing-dead Spartina alterniflora, fungi appeared to play a greater role in litter decomposition than did bacteria (May 1974. Sieburth et al. 1974, Gessner 1977, 1978, Rublee et al. 1978, Lee et al. 1980, Newell \& Hicks 1982). For example, Newell \& Hicks (1982) found that fungal hyphal volume was $0.27 \mathrm{~mm}^{3}$ per $\mathrm{mm}^{3}$ of cordgrass leaf, while bacterial volume was less than $3 \%$ of the fungal volume. Thus, when a detritivore consumes a particle derived from S. alterniflora, the animal ingests not only plant material and bacterial cells, but also a significant amount of fungal hyphae. In addition, the relative proportion of bacteria versus fungi consumed by detritivores may be significant in providing detritivores with a balance of essential fatty acids, amino acids, sterols, vitamins and other growth factors (Phillips 1984).

The present study examined the quantitative contribution of both bacteria and fungi to the detrital complex. While the total microbial standing crop may be critical in terms of the quantity of readily assimilable carbon and energy of detritus from a particular plant, variation in the proportion of bacterial versus fungal biomass supported by the decaying vegetation over the entire decay period may be more significant in terms of the total nutritional requirements of detritivores.

\section{MATERIALS AND METHODS}

In order to compare changes in bacterial and fungal biomass throughout the decomposition of different 
plant materials, fresh plants with no visible coating of epiphytic organisms were used so that starting materials were of similar age, and thus, stage of decomposition. Leaves of the seagrasses Thalassia testudinum, Syringodium filiforme, and Halodule wrightii were picked from plants in Pine Channel, Big Pine Key, Florida. Yellow leaves were picked from the branches of red mangrove Rhizophora mangle growing in Pine Channel. The seagrasses were kept in ice chests with aerated seawater, while the mangrove leaves were kept in nylon mesh bags. All plant materials were stored out of direct sunlight and processed within $24 \mathrm{~h}$ of collection.

The fresh weight of plant material placed in litter bags was determined using the procedure of Zieman (1968). Fresh weight: dry weight: ash-free dry weight ratios were determined for each plant type as described by Robertson (1982). Numbered litter bags (nylon mesh with $1 \mathrm{~mm}$ openings) containing 20 to $25 \mathrm{~g}$ (fresh weight) of plant material were anchored to the sediment surface in $1 \mathrm{~m}$ of water in Pine Channel. Bags were withdrawn after $7,14,28$, and $42 \mathrm{~d}$ of incubation beginning in early July. At each sampling time, 3 bags of each species were retrieved, and the contents washed free of sediment and animal matter. The contents of each bag were weighed and 3 subsamples ( 1 to $2 \mathrm{~g}$ wet weight per subsample) of the detritus were withdrawn and placed in $50 \mathrm{ml}$ of filtered $(0.2 \mu \mathrm{m}$ pore size) seawater (FSW) containing $2 \%$ formaldehyde for later determination of bacterial and fungal abundance. The remaining detritus was acid-washed in $10 \% \mathrm{HCl}$ to remove any carbonates and then freeze-dried. Three subsamples of the lyophilized material were combusted at $500{ }^{\circ} \mathrm{C}$ for $6 \mathrm{~h}$. For the detritus collected at each sampling time, the mean wet weight.dry weight: ash free dry weight ratio was determined for the material remaining in each litter bag and this ratio used to convert the wet weight of the contents of each bag to ash-free dry weight.

An additional set of bags was retrieved after $262 \mathrm{~d}$ of incubation, but all of the plant material was gone from the litter bags. In order to assess the effect of an extended incubation, detrital material was collected from the bottom of Pine Channel immediately adjacent to the experimental site. The plant material was not decomposed to the extent that it was unidentifiable; however, it was probable that it had been decomposing for longer than $42 \mathrm{~d}$. This material was handled exactly as described for that taken from the litter bags except that it was impossible to determine any weight-loss characteristics.

Bacterial abundance was determined using the acridine orange direct count (AODC) technique (Hobbie et al. 1977) as modified by Rublee et al. (1978) for detritus. The abundance of fungal hyphae was estimated using the agar-film technique of Jones \& Mollison (1948) as modified by Newell \& Hicks (1982), except that plant homogenates used in the present study for both AODCs and agar films were prepared from formalin-preserved plant material (as described above), processed at medium speed in an Oster blender for $5 \mathrm{~min}$ in the $50 \mathrm{ml}$ of FSW originally used to fix the sample. Portions of well-mixed homogenates were used to prepare AODCs and agar films. Agar films were examined using both phase-contrast and epifluorescence microscopy; however, biovolume was calculated from the hyphal intersections estimated with phase-contrast since the number of intersections was greater than that obtained using epifluorescence. It is possible that some filaments recorded as fungal hyphae were actually algal or cyanobacterial filaments; thus our estimates of fungal biomass, and therefore total microbial biomass, may be slightly inflated. Filaments that were clearly cyanobacterial or algal were not counted so that the numbers presented here are better estimates of 'fungal biomass' than of 'filamentous biomass'.

Microbial volume was determined for bacteria by measuring 20 cells in each of 10 microscope fields per sampling period, and for fungi by measuring the diameter of all hyphal fragments in 10 fields per sampling period using phase-contrast microscopy. Microbial mass was calculated as: (dry-mass density) $\times$ (biovolume unit $^{-1}$ substrate mass) assuming a dry-mass

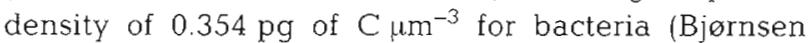
1986), of $0.9 \mathrm{~g} \mathrm{~cm}^{-3}$ for fungi (Newell \& Statzell-Tallman 1982), and a carbon/dry mass ratio of $50 \%$ for bacteria (Luria 1960).

\section{RESULTS AND DISCUSSION}

The dry weight of all seagrass detritus decreased rapidly at first, presumably due to leaching of soluble organic material, which coincided with a rapid increase in microbial biomass (Fig. 1). Subsequent weight loss for all seagrass material was much slower, probably reflecting microbial activity on the more refractory particulate matter remaining. Changes in bacterial abundance among the plant types varied after $14 \mathrm{~d}$ of incubation, with cell counts for Syringodium filiforme decreasing, those for Thalassia testudinum increasing (but more slowly than earlier in the decomposition), and those of Halodule wrightii leveling off. For Rhizophora mangle, the initial rate of weight loss and increase in bacterial abundance was much slower than for the seagrasses, and the abundance continued to increase at a relatively constant rate throughout the incubation (Fig. 1).

For the detritus collected adjacent to the study site 

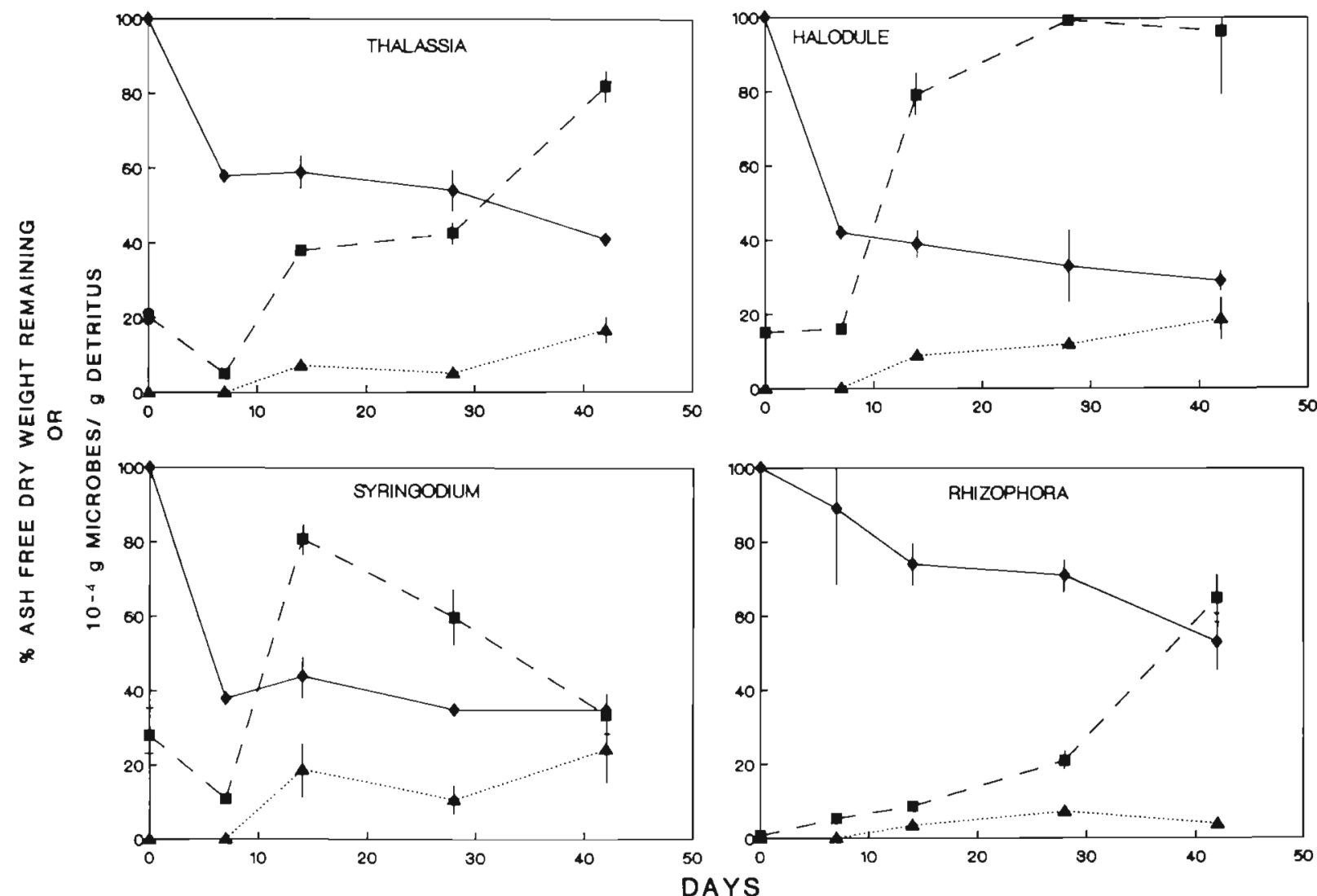

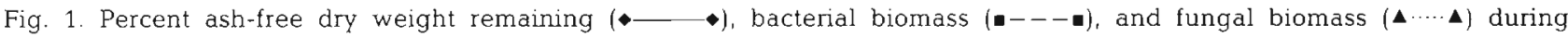
decomposition of Thalassia testudinum, Halodule wrightii, Syringodium filiforme, and Rhizophora mangle. For those data points with no error bars, the standard error of the mean is less than the height of the symbol

that had decomposed for longer than $42 \mathrm{~d}$ (extended decay), the standing crop of cells was highest for Syringodium filiforme, followed by Halodule wrightii, and Rhizophora mangle (Fig. 2). This is in general agreement with the $42 \mathrm{~d}$ samples in which the concentration of microbes was greater for the seagrasses, with the exception of $S$. filiforme, than for the mangrove. It appears that continued decay does not alter the relative microbial standing crop associated with the various detrital materials.

No fungal hyphae were detected in any of the samples until Day 14 (Fig. 1), and when detected, they were a small fraction of the total microbial biomass. In only one sample did the fungal biomass constitute more than $40 \%$ of the total microbial biomass during the $42 \mathrm{~d}$ of incubation or in the extended decay samples (Table 1), and the normal range was 0 to $20 \%$. These estimates of the small contribution of fungal biovolume to the microbiota are consistent with those of Newell (1981) who was unable to find any measurable fungal volume associated with the temperate seagrass Zostera marina. Estimates of hyphal abundance made by this method (Newell 1981 and the present study) may be underestimates, since Newell et al. (1986) showed that conservatively interpreted agar films give consistently lower values than do either the ergosterol or ELISA techniques. Nevertheless, the percentage of the total microbial biomass attributable to fungi for the tropical seagrasses and mangrove in this study is much less than for Spartina alterniflora in other locations where similar microscopic techniques were used for estimation of hyphal fungi (Newell \& Hicks 1982).

The pattern of microbial succession on the decaying plant material used in this study also differs from that observed for Spartina alterniflora by Gessner et al. (1972), who found that living cordgrass is initially colonized by a parasitic fungus Buergenerula spartinae. Although quantitative measurements were not made, the authors asserted that during senescence, this fungus and other saprobic fungi developed a substantial biomass on the standing-dead plant material. Colonization by bacteria followed, but the fungal biomass continued to dominate during decomposition. Benner et al. (1984) examined the relative contributions of bacteria and fungi to the rates of ${ }^{14} \mathrm{C}$-labeled $S$. alterniflora material degradation in salt-marsh sediments and found that bacterial assemblages were the principal decomposers of the lignocellulosic fraction while bac- 




Fig. 2. Total (shaded), bacterial (cross-hatched), and fungal (black) biomass associated with Thalassia testudinum, Rhizophora mangle, Halodule wrightii, and Syringodium filiforme detritus after extended decay

Table 1. Changes in contribution of bacteria to total microbial biomass associated with decomposing litter from several plant species over time. Values are percentages of total microbial biomass attributable to bacteria

\begin{tabular}{|lccccccc|}
\hline Plant & \multicolumn{6}{c}{ Day } \\
& 0 & 7 & 14 & 28 & 42 & Extended \\
\hline Thalassia testudinum & 100 & 100 & 84 & 90 & 83 & 93 \\
Rhizophora mangle & 100 & 100 & 72 & 75 & 94 & 99 \\
Halodule wrightii & 100 & 100 & 90 & 89 & 85 & 100 \\
Syringodium filiforme & 100 & 100 & 81 & 85 & 58 & 98 \\
\hline
\end{tabular}

terial assemblages and 3 fungal isolates were capable of degrading the non-lignocellulosic fraction of $S$. alterniflora material. These data suggest that bacteria are likely to predominate during later stages of decomposition when the remaining detritus is presumably more refractory, i.e. lignocellulosic. In the present study, bacteria were the principle colonizers of living seagrass and mangrove leaf surfaces, and bacteria predominated throughout decomposition with fungi invading the tissues only after $2 \mathrm{wk}$ of incubation.

The total microbial biomass associated with decomposing seagrasses and mangroves constituted a small portion of the detrital mass; at no time during the period of decomposition was the microbial biomass greater than $1.2 \%$ of the detrital complex and in most cases was much less than $1.0 \%$. Using the assumptions that (1) detritivores consume entire particles (plant plus microbes), (2) a typical ingestion rate for detritivores is $0.24 \mathrm{mg} \mathrm{C}$ per $\mathrm{mg}$ dry weight of invertebrate per day (Roman 1984a, b), (3) the assimilation efficiency of microbial cells by invertebrates is $70 \%$ (Kofoed 1975a, b, Lopez \& Levinton 1978), (4) the specific metabolic rate of invertebrates is $0.1 \mathrm{kcal} \mathrm{g}^{-1} \mathrm{~d}^{-1}$ (Fenchel \& Jørgensen 1977), (5) the individual invertebrate biomass is $1 \times 10^{-3} \mathrm{~g}$ (Fenchel \& Jorgensen 1977), (6) the detrital complex is on average $0.44 \%$ (range of 0.007 to $1.13 \%$ ) microbial biomass (data from this study), and (7) microbial cells are $100 \%$ carbohydrate (a generous assumption), then the amount of energy (and presumably carbon) that this hypothetical detritivore would obtain by utilizing only the microbial cells from the detrital complex may be calculated as:

(1) Using the mean \% microbial biomass of the detrital complex as $0.44 \%$, and assuming that $50 \%$ of the microbial biomass and $40 \%$ of the detrital mass is carbon, then the microbial contribution of carbon in $1 \mathrm{~g}$ of detrital carbon $=0.0055 \mathrm{~g}$ microbial $\mathrm{C}(\mathrm{g}$ detrital C) ${ }^{-1}$.

(2) The invertebrate ingestion rate of microbial carbon is:

[0.24 mg detrital C (mg dw invertebrate) $\left.)^{-1} \mathrm{~d}^{-1}\right] \times$

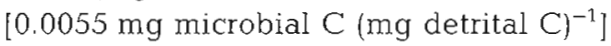

$=0.00132 \mathrm{mg}$ microbial $\mathrm{C}(\mathrm{mg} \mathrm{dw} \text { invertebrate })^{-1} \mathrm{~d}^{-1}$.

(3) If all of the microbial carbon is glucose, then:

[0.00132 $\mathrm{mg}$ microbial C ( $\mathrm{mg} \mathrm{dw}$ invertebrate) ${ }^{-1} \mathrm{~d}^{-1}$ ] $\times$

[180 g glucose mole $\mathrm{g}^{-1} / 72 \mathrm{~g} \mathrm{C}$ mole $^{-1}$ ]

$=0.0033 \mathrm{mg}$ glucose $(\mathrm{mg} \mathrm{dw} \text { invertebrate })^{-1} \mathrm{~d}^{-1}$

(4) Given that there are $3.8 \mathrm{cal}(\mathrm{mg} \text { glucose })^{-1}$, and assuming an invertebrate assimilation efficiency of $70 \%$, then

[0.0033 $\mathrm{mg}$ glucose $\left.(\mathrm{mg} \mathrm{dw} \text { invertebrate })^{-1} \mathrm{~d}^{-1}\right] \times$

$$
\begin{gathered}
{\left[3.8 \mathrm{cal}(\mathrm{mg} \mathrm{glucose})^{-1}\right] \times[0.7]} \\
=0.0088 \mathrm{cal}(\mathrm{mg} \mathrm{dw})^{-1} \mathrm{~d}^{-1}
\end{gathered}
$$

(5) With an invertebrate metabolic rate of $0.1 \mathrm{cal}(\mathrm{mg}$ $\mathrm{dw}$ invertebrate $)^{-1} \mathrm{~d}^{-1}$, then the daily ingestion of $\mathrm{mi}$ crobial carbon would provide:

$\left[0.0088 \mathrm{cal}\right.$ ( $\mathrm{mg}$ dw invertebrate) $\left.{ }^{-1} \mathrm{~d}^{-1}\right] \times$

$\left[\mathrm{mg} \mathrm{dw}\right.$ invertebrate $\left.\mathrm{d}(0.1 \mathrm{cal})^{-1}\right] \times 100$ $=8.8 \%$ of daily invertebrate carbon requirement $\mathrm{d}^{-1}$ Similar calculations using the lowest and highest microbial biomasses gave a range of 0.14 to $22.5 \%$. It is important to note that these numbers represent the maximum contribution of microorganisms to detritivore $C$ requirements since the fungal biomass may have included some algal biomass. Therefore, it is unlikely that detritivores which ingest whole detrital particles rely solely on the standing crop of bacteria and fungi as their sole source of carbon and energy. The data presented here are estimates of microbial standing crop. and thus do not indicate the microbial productivity and 
carbon flow through the microbial community. If plant carbon is being rapidly incorporated into microbial biomass and is being selectively grazed at an equivalent rate, then the standing crop would not be a good measure of the microbial carbon available to detritivores. We are presently measuring bacterial productivity along with bacterial and fungal standing crop associated with decomposing Zostera marina and Spartina alterniflora to establish time-dependent carbon fluxes in Chesapeake Bay.

Even though microorganisms may not be the primary source of detritivore carbon and energy, they may be the major source of essential nutrients such as fatty acids, essential amino acids, sterols, vitamins, and other growth factors. Phillips (1984) suggests that detritivores could require both bacteria as a source of essential amino acids or B-complex vitamins and fungi (or other eucaryotes) to provide sterols. If detritivores require both bacteria and fungi in order to provide a balance of essential nutrients, the present data suggest that the plant material may not be a suitable food source initially because of the absence of fungi, but that as the plants decompose they may, at least at some time during the decay process, have similar potentials for providing balanced dietary requirements to consumers.

Acknowledgements. We thank R. D. Fallon and W E. Odum for manuscript review. This work is a result of research sponsored in part by NOAA Office of Sea Grant, U.S. Department of Commerce, under Grant No. NA85AA-D-SG016 to the Virginia Graduate Marine Science Consortium and Virginia Sea Grant College Program. The U.S. Government is authorized to produce and distribute reprints for governmental purposes notwithstanding any copyright notation that may appear hereon.

\section{LITERATURE CITED}

Benner, R., Newell, S. Y., Maccubbin, A. E., Hodson, R. E. (1984). Relative contribution of bacteria and fungi to rates of degradation of lignocellulosic detritus in salt-marsh sediments. Appl. environ. Microbiol. 48: 36-40

Bjømsen, P. K. (1986). Automatic determination of bacterioplankton biomass by image analysis. Appl. environ. Microbiol. 51: 1199-1204

Cammen, L. (1980). The significance of microbial carbon in the nutrition of the deposit feeding polychaete Nereis succinea. Mar. Biol. 61: 9-20

Fenchel, T., Jørgensen, B. B. (1977). Detritus food chains of aquatic ecosystems: the role of bacteria. In: Alexander, $M$. (ed.) Advances in microbial ecology, Vol. 1. Plenum Press, New York, p. 1-58

Findlay, S., Meyer, J. L. (1984). Significance of bacterial biomass and production as an organic carbon source in lotic detrital systems. Bull. mar. Sci. 35: 318-325

Gessner, R. V (1977). Seasonal occurrence and distribution of fungi associated with Spartina alterniflora from a Rhode Island estuary. Mycologia 69: 477-491
Gessner, R. V. (1978). Spartina alterniflora seed fungi. Can. J. Bot. 56: 2942-2947

Gessner, R. V., Goos, R. D., Sieburth, J. McN. (1972). The fungal microcosm of the internodes of Spartina alterniflora. Mar Biol. 16: 269-273

Hobbie, J. E., Daley, R. J., Jasper, S. (1977). Use of Nuclepore filters for counting bacteria by fluorescence microscopy Appl environ. Microbiol. 35: 1225-1228

Iverson. T M. (1973). Decomposition of autumn-shed leaves in a spring brook and its significance for the fauna. Arch. Hydrobiol. 72: 305-312

Jones, J. G., Mollison, J. E. (1948). A technique for the quantitative estimation of soil microorganisms. J. gen. Microbiol. 2: 54-69

Kofoed, L. H. (1975a). The feeding biology of Hydrobia ventrosa (Montagu). I. The assimilation of different components of the food. J. exp. mar. Biol. Ecol. 19: 233-241

Kofoed, L. H. (1975b). The feeding biology of Hydrobia ventrosa (Montagu). II. Allocation of the components of the carbon-budget and the significance of the secretion of dissolved organic material. J. exp. mar. Biol. Ecol. 19: $243-256$

Lee, C., Howarth, R. W., Howes, B. L. (1980). Sterols in decomposing Spartina alterniflora and the use of ergosterol in estimating the contribution of fungi to detrital nitrogen. Limnol. Oceanogr. 25: 290-303

Lopez, G. R., Levinton, J. S. (1978). The availability of microorganisms attached to sediment particles as food for $\mathrm{Hy}$ drobia ventrosa Montagu (Gastropoda, Prosobranchia). Oecologia (Berl.) 32: 263-275

Lopez, G. R., Levinton, J. S., Slobodkin, L. B. (1977). The effect of grazing by the detritivore Orchestia grillus on Spartina litter and its associated microbial community. Oecologia (Berl.) 30: 111-127

Luria, S. E. (1960). The bacterial protoplasm: composition and organization. In: Gunsalus, I. C., Stanier, R. Y (eds.) The bacteria; Vol. 1. Academic Press, New Vork, p. 1-34

May, M. S. (1974). Probable agents for the formation of detritus from the halophyte, Spartina alterniflora. In: Reimold, R. J., Queen, W. H. (ed.) Ecology of halophytes. Academic Press, New York, p. 429-440

Newell, R. C. (1965). The role of detritus in the nutrition of two marine deposit-feeders, the proso-branch Hydrobia ulvae and the bivalve Macoma balthica. Proc. zool. Soc. Lond. 144: $25-45$

Newell, R. C., Field, J. (1983). The contribution of bacteria and detritus to carbon and nitrogen flow in a benthic community. Mar. Biol. Lett. 4: 23-36

Newell, S. Y (1981). Fungi and bacteria in or on leaves of eelgrass (Zostera marina L.) from Chesapeake Bay. Appl, environ. Microbiol. 41: 1219-1224

Newell, S. Y., Fallon, R. D., Miller, J. D. (1986). Measuring fungal-biomass dynamics in standing-dead leaves of a salt-marsh vascular plant. In: Moss, S. T. (ed.) The biology of marine fungi. Cambridge Univ. Press, Cambridge, p. $19-25$

Newell, S. Y., Hicks, R. E. (1982). Direct-count estimates of fungal and bacterial biovolume in dead leaves of smooth cordgrass (Spartina alterniflora Loisel.). Estuaries 5: $246-260$

Newell, S. Y., Statzell-Tallman, A. (1982). Factors for conversion of fungal biovolume values to biomass, carbon and nitrogen: variation with mycelial ages, growth conditions and strains of fungi from a salt marsh. Oikos 39: 261-268

Phillips, N. W (1984). Role of different microbes and substrates as potential suppliers of specific, essential nutrients to marine detritivores. Bull, mar Sci. 35: 283--298 
Robertson, M. L. (1982). Decomposition of seagrasses. M.S. thesis, Univ. of Virginia, Charlottesville

Roman, M. R. (1984a). Utilization of detritus by the copepod, Acartia tonsa. Limnol. Oceanogr 29: 949-959

Roman, M. R. (1984b). Ingestion of detritus and microheterotrophs by pelagic marine zooplankton. Bull. mar. Sci. 35: $477-494$

Rublee, P. A. (1982). Seasonal distribution of bacteria in salt marsh sediments in North Carolina. Estuar. coast. Shelf Sci. 15: 67-74

Rublee, P. A., Cammen, L. M., Hobbie, J. E. (1978), Bacteria in a North Carolina marsh: standing crop and importance in the decomposition of Spartina alterniflora. Univ. of North Carolina Sea Grant Publ. UNC-SG-78-11

Sieburth, J. McN., Brooks, R. D., Gessner, R. V., Thomas, C D. Tuttle, J. L. (1974). Microbial colonization of marine plant surfaces as observed by scanning electron microscopy. In: Colwell, R. R., Morita, R. Y (eds.) Effect of the ocean environment on microbial activities. Univ. Park Press, Baltimore, p. 418-432

Zieman, J. C. (1968). A study of the growth and decomposition of the seagrass Thalassia testudinum. M. S. thesis, Univ. of Miami, Coral Gables

This article was presented by Dr S. Y. Newell; it was accepted for printing on October 2, 1987 